\title{
CoviD-19 ve Aşı Haberlerinin Borsa İstanbul Sektör Endekslerine Etkisi: Bir Olay Etüdü Analizi
}

\author{
Kemal ÖZDEMIR (https://orcid.org/0000-0003-0644-6460), Aydin Adnan Menderes University, Turkey; \\ kemal.ozdemir@adu.edu.tr
}

Burcu HIÇYILMAZ (https://orcid.org/0000-0003-3501-2012), Aydin Adnan Menderes University, Turkey; burcu.yilmaz@adu.edu.tr

\section{The Effects of Covid-19 and Vaccine News on The BIST Industrial Indexes: A Case Study Analysis}

\begin{abstract}
The coronavirus (Covid-19) originated from China. It spread across the globe, and the news regarding the development of various vaccines has affected the economies of numerous countries and capital markets alongside the BIST industrial indexes. This study investigates how the declaration of the pandemic by the World Health Organization (WHO), the news of the first case of the virus, the first death caused by the virus and the first shipment of the vaccine for the virus impacted the BIST industrial indexes by way of using daily data and constructing a case study. According to the results obtained from the analysis, it was detected that the first event day and the second event day caused mostly abnormal losses on the sectors, and the third event day caused positive abnormal returns on the sectors. As a result of the news, it has been determined that the sector with the most abnormal returns and losses is tourism.

Keywords

JEL Classification Codes :

\section{Covid-19, Stock Markets, Borsa İstanbul, Sector Indices, Event Study.}

I00, G10, G14.

\section{$\ddot{\mathbf{O z}}$}

Çin'de ortaya çıkan ve hızla dünyaya yayılan korona virüs (Covid-19) ve bu virüse yönelik geliştirilen aşı haberleri birçok ülke ve sermaye piyasası ile birlikte Borsa İstanbul sektör endekslerini de etkilemiştir. Bu çalışmada, Dünya Sağlık Örgütü (DSÖ)'nün pandemi ilanı ve Türkiye'de ilk vaka, Türkiye'de ilk ölüm ve Türkiye'ye ilk aşı geliş haberlerinin Borsa İstanbul sektör endeksleri üzerindeki etkisi günlük veriler kullanılarak olay etüdü yöntemi ile incelenmiştir. Analiz sonucunda ilk olay günü ve ikinci olay gününün sektörler üzerinde çoğunlukla anormal kayılara, üçüncü olay gününün ise sektörler üzerinde pozitif anormal getirilere neden olduğu tespit edilmiştir. Haberler neticesinde en çok anormal getiri ve kayıpların yaşandığı sektörün turizm olduğu belirlenmiştir.
\end{abstract}

Anahtar Sözcükler $\quad$ : Covid-19, Hisse Senedi Piyasas1, Borsa İstanbul, Sektör Endeksi, Olay Etüdü. 
Özdemir, K. \& B. Hiçyılmaz (2022), "COVID-19 ve Aş1 Haberlerinin Borsa İstanbul

Sektör Endekslerine Etkisi: Bir Olay Etüdü Analizi”, Sosyoekonomi, 30(51), 471-486.

\section{Giriş}

İlk olarak 31 Aralık 2019'da nedeni bilinmeyen bir zatürre olarak Çin'den Dünya Sağlık Örgütü (DSÖ)'ne bildirilen vaka sonrasında, önce Çin'e sonra dünya ülkelerine yayılan ve Covid-19 olarak adlandırılan bulaşıcı hastalık, 30 Ocak 2020'de Dünya Sağlık Örgütü tarafından uluslararası halk sağlığı acil durumu olarak ilan edilmiştir. 11 Mart 2020 tarihinde ise DSÖ Genel Sekreteri'nin açıklamasıyla DSÖ tarafından pandemi olarak ilan edilmiştir.

Covid-19, hem coğrafik açıdan hem de etkilediği ekonomi, eğitim, sağlık, sosyal hayat, çevre, turizm gibi alanlar açısından değerlendirildiğinde oldukça geniş çaplı etkiler yaratmıştır. Bunlardan biri olan borsa getirileri de büyük olaylara tepki veren bir alan olarak Covid-19 gelişmelerinden olumsuz etkilenmiştir (Alam et al., 2020; Ashraf, 2020; Goodell \& Huynh, 2020; He et al., 2020; Liu et al., 2020; Singh et al., 2020; Heyden \& Heyden, 2021; Pandey \& Kumari, 2021; Sun et al. 2021). Sektör ya da firma düzeyinde getirilere bakıldığında ise etkinin yönünün ve boyutunun birimler arasında farklılaştı̆̆ gözlemlenmiştir (Kılıç, 2020; Maneenop \& Kotcharin, 2020; Göker, 2020; Peker \& Demirhan, 2020; Öztürk, 2020; Tayar, 2020).

Literatürde yer alan çalışmalar genellikle Covid-19'un halk sağlığı acil durumu ilan edilişi, pandemi olarak ilan edilişi, ülkedeki ilk vakanın ve ilk ölümün ortaya çıkış tarihi gibi virüsün çıkışına yönelik tarihlerin etkilerini araştırmaktadır. Bu çalışmada virüsün çıkışına yönelik 11 Mart 2020 Türkiye'de ilk vaka ve DSÖ’nün pandemi ilanı vakası ile 17 Mart 2020 Türkiye'de Covid-19 kaynaklı ilk ölüm vakasının yanı sıra, literatürde bir eksiklik olan, aşı gelişmelerinin Borsa İstanbul sektör getirilerine olan etkisinin yönü ve büyüklüğünün ortaya konulması amaçlanmaktadır. Dünya'da ve Türkiye'de aşıyla ilgili birçok haber yayımlanmıştır. Fakat bu haberlerin Türkiye özelinde ilk somut etkisi 30 Aralık 2020 CoronaVac aşısının ilk partisinin Türkiye'ye gelmesidir. Üçüncü olay günü olarak alınan bu tarih normalleşme sürecine 1şı yakan, vatandaşlara yönelik aşı uygulamasının başlayacağına ilişkin öncü bir gösterge niteliğindedir. Çalışmada, Covid-19 kaynaklı yaşanan finansal piyasalardaki negatif algının, bu olumlu nitelikte görülebilecek aşı haberi ile finansal piyasalardaki negatif algıyı azaltabileceği öngörülerek hangi sektör endeksleri üzerinde nasıl bir etkisi olacağının tespit edilmesi amaçlanmıştır.

Farklı olay günleri neticesinde hangi sektörlerin anormal getiri elde ettiği hangi sektörlerin anormal kayba uğradığı tespit edilmekte ve sektör özelinde değerlendirmelerde bulunulmaktadır. Yapılacak analiz ve değerlendirmeler neticesinde haberin niteliğine bağlı olarak hangi sektör endeksinde anormal getiri ve kayıpların oluştuğunun tespit edilmesi, daha sonra ortaya çıkacak benzer haberlerde yatırımcının öngörüsünün artmasına ve daha doğru yatırım kararları almasına yol gösterici nitelikte olacaktır.

Bu amaçla bir sonraki bölümde, literatürde yer alan çalışmalar özetlenmekte; üçüncü bölümde analizde kullanılan veri ve yöntem ortaya konmakta; dördüncü bölümde analizden elde edilen bulgular raporlanmakta; son bölümde ise sonuç ve çıkarımlar aktarılmaktadır. 
Özdemir, K. \& B. Hiçyılmaz (2022), "COVID-19 ve Aşı Haberlerinin Borsa İstanbul

Sektör Endekslerine Etkisi: Bir Olay Etüdü Analizi”, Sosyoekonomi, 30(51), 471-486.

\section{Literatür Taraması}

Çin ve ABD başta olmak üzere, Covid-19 ile ilgili gelişmelerin birçok gösterge üzerine etkisinin farklı ülkeler için incelendiği çok sayıda çalışma 2020 ve 2021 yılı literatüründe mevcuttur. Bu göstergeler arasında çok kısa dönemli, kısa dönemli ve uzun dönemli çıkarımların yapılabildiği hisse senedi piyasası da yer almaktadır. Covid-19 pandemisinin çeşitli ülkelerin borsalarına etkisi, araştırmanın amacına göre farklı yöntemler kullanılarak analiz edilmiş̧ir. Bu başlık altında sırasıyla, Türkiye haricindeki ülkeler ve Türkiye için olay etüdü ve diğer yöntemleri kullanan ilgili önemli çalışmalar ve bu çalışmalardan elde edilen sonuçlar özetlenmektedir.

Chowdhury \& Abedin (2020) Covid-19 pandemisinin Dow Jones ve S\&P 500 endekslerine etkisini GARCH, VAR ve olay etüdü yöntemlerini kullanarak araştırmaktadır. 1 Ocak 2020-30 Nisan 2020 dönemi günlük verileri kullanılmıştır. Olay günü olarak ilk Covid-19 hastasının tespit edildiği gün olan 20 Ocak 2020 alınmıştır. Sonuç olarak ABD borsasının doğrulanmış vakalara ve ölüm vakalarına olumsuz tepki verdiği; ölüm vakalarının ayrıca borsa oynaklığı üzerinde önemli bir etkisinin olduğu sonucuna ulaşılmıştır. Salgının belirsizliği ve yarattığı ekonomik kayıpların, piyasayı ciddi şekilde değişken ve tepkisel hale getirdiği vurgulanmıştır.

ABD için araştırma yapan çalışmalardan biri olan Yong \& Laing (2020), DSÖ'nün "halk sağlığı acil durumu ilanı" olayına Amerikan borsasına kayıtlı tüm firmaların tepkisini uluslararas1 etkilenme durumuna odaklanarak olay etüdü yöntemi ile incelemektedir. Elde ettikleri sonucuna göre yurtdışı satışlar, yurtdışı varlıklar, ihracat ve ithalat gibi uluslararası maruziyet yaratan durumlar, kısa vadede standartlaştırılmış kümülatif anormal getiriler ile negatif ilişkiliyken; bu etki uzun dönemde tersine dönmektedir. Uzun vadede uluslararasılaşma durumu, Covid-19'un yarattığı şoklara daha dirençli olunmasına etki etmektedir.

ABD için analiz yapan bir diğer çalışma Goodell \& Huynh (2020)'dir. S\&P 500 bileşik endeksine kayıtlı 49 sektörün günlük hisse senedi getirilerini kullanarak sektörlerin Covid-19 haberlerine tepkisini, yatırımcıların Covid-19'a olan ilgisinin düzeyi ile birlikte ele alarak olay etüdü analizi yöntemi ile incelemektedir. Çalışmada farklı olayların etkilerine bakılmıştır. 26 Şubat Kaliforniya'da doğrulanmış seyahat geçmişi olmayan ilk yerel vakaya göre etkiler araştırıldığında elde edilen sonuçlara göre 15 sektörün getirileri bu habere tepki vermiştir. Tüm sektörlerin yüzde otuzu negatif anormal getiri elde etmiştir. Özellikle, hizmetler ve kamu hizmetleri en hassas tepkiyi vermiştir. Restoranlar, oteller ve moteller de kamu hizmetlerinin yanı sıra olumsuz tepkiler yaşayan sektörlerin arasında tespit edilmiştir. Bu olayın dışında iki farklı tarih daha ele alınmıştır: i) ABD'de de doğrulanan ilk vakalar (20 Ocak 2020) ve ii) uluslararası öneme sahip halk sağlığı acil durum duyurusu (30 Ocak 2020)'dir. Fakat bu tarihlerde, beklenenin aksine, piyasaların tepkisiz olduğu ve 26 Şubat'a kadar da piyasanın tepkisiz kaldığı sonucuna varılmıştır. 
Özdemir, K. \& B. Hiçyılmaz (2022), “COVID-19 ve Aş1 Haberlerinin Borsa İstanbul

Sektör Endekslerine Etkisi: Bir Olay Etüdü Analizi”, Sosyoekonomi, 30(51), 471-486.

He et al. (2020) Çin endüstrilerinin Covid-19 salgınına tepki eğilimlerini ve pazar performansını olay etüdü yöntemini kullanarak incelemektedir. Olay günü olarak Wuhan'ın kapatıldığı 23 Ocak 2020 tarihi alınmıştır. Bu amaçla Shanghai ve Shenzhen borsalarına kayıtlı 2895 firmanın 3 Haziran 2019- 13 Mart 2020 dönemi verileri kullanılmıştır. Analiz sonucu olarak ulaştırma, madencilik, elektrik ve ısıtma ve çevre endüstrilerinin pandemiden olumsuz etkilendiği; imalat, bilgi teknolojisi, eğitim ve sağlık sektörlerinin ise pandemiye karşı dirençli olduğu ortaya konmuştur.

Huo \& Qiu (2020) Çin hisse senedi piyasasının 2020'de ani Covid-19 salgınına, özellikle de karantina duyurusuna nasıl tepki verdiğini incelemektedir. Çalışmada, yatırımcıların karantinaya aşırı tepkileri nedeniyle hem sektör düzeyinde hem de firma düzeyinde tersine dönüşler yaşandığı tespit edilmiştir. Wuhan'ın kapatıldığ 23 Ocak 2020 için olay penceresinde pozitif kümülatif anormal getirilere sahip endüstri ve firma seviyesindeki hisse senetleri için tersine çevirmelerin daha güçlü olduğu gözlemlenmiştir. Ayrıca daha düşük kurumsal mülkiyete (institutional ownership) sahip hisse senetleri için aşırı tepkilerin daha güçlü olduğunu ve bu sebeple perakende yatırımcıların Covid-19'a daha güçlü tepki verdiğini göstermişlerdir.

Al-Awadhi et al. (2020) Hang Seng endeksi ve Shanghai hisse senedi bileşik endeksinin Covid-19'a verdiği tepkiyi 10 Ocak-16 Mart 2020 dönemi için Hang Seng Endeksi ve Şanghay Kompozit Endeksi'nde yer alan firmaların verilerini kullanarak panel veri regresyonu ile araştırmaktadır. Analiz sonucuna göre Covid-19'un borsa getirilerini olumsuz etkilediğini tespit etmişlerdir. Hisse senedi getirilerinin, hem teyit edilen toplam vakalardaki günlük büyüme hem de Covid-19'un neden olduğu toplam ölüm vakalarındaki günlük büyüme ile önemli ölçüde negatif ilişkili olduğu ortaya konulmuştur.

Xiong et al. (2020) 23 Ocak 2020'de Wuhan'ın karantinaya alınmasına Çin hisse senedi piyasasına kayıtlı firmalarının nasıl tepki verdiğini araştırmaktadır. Bu amaçla tüm Çin hisse senedi piyasasındaki firmaları (eksik verisi olan firmalar hariç) örneklem olarak alınmıştır. Covid-19 salgınına karşı piyasa tepkisinin, virüse karşı savunmasız olan endüstrilerde ve kurumsal yatırımcıları yüksek olan firmalarda daha yoğun olduğu tespit edilmiştir. Daha büyük ölçekli, daha iyi karlılık ve büyüme fırsatı, daha yüksek birleşik kaldıraç ve daha az sabit varlığa sahip firmaların diğer firmalara oranla Covid-19'dan daha az etkilendikleri vurgulanmıştır.

Covid-19'un Çin borsasına etkisini inceleyen bir diğer çalışma olan Sun et al. (2021), bireysel yatırımcı duyarlılığının getiriler üzerindeki etkisini olay etüdü analizi ile incelemiştir. Elde edilen sonuçlara göre, olay günü sonrasında hem hisse senedi getirileri hem de bireysel yatırımcı duyarlılığı olumsuz tepki vermiştir. Olay penceresi boyunca standart sapmanın artması Çin borsa getirisinin azaldığı ve salgın nedeniyle oynaklığın arttığı şeklinde yorumlanmıştır. Ancak buna ek olarak bu etkinin tersine döndüğü çarpıcı bir sonuç da gözlemlenmiştir. Olay sonrası pencerede hem getiri hem de yatırımcı duyarlılı̆̆ yükselerek, Covid-19 olayı öncesi ortalama seviyeyi aşmıştır. 
Özdemir, K. \& B. Hiçyılmaz (2022), “COVID-19 ve Aşı Haberlerinin Borsa İstanbul Sektör Endekslerine Etkisi: Bir Olay Etüdü Analizi”, Sosyoekonomi, 30(51), 471-486.

Alam et al. (2020) Covid-19'un sebep olduğu kısıtlama döneminin hisse senedi piyasası üzerindeki etkisini ve piyasa etkisinin kısıtlama öncesinde ve sonrasında aynı olup olmayacağını Hindistan için incelemektedir. Bombay Borsası'nda listelenen 31 şirketten oluşan bir örneklem rastgele seçilerek 24 Şubat 2020-17 Nisan 2020 dönemi verileri ile olay etüdü yöntemi kullanılarak analiz edilmiştir. Sonuç olarak kısıtlama öncesi dönemde yatırımcıların paniğe kapıldığı ve bu durumun olumsuz ortalama anormal getirilere yansıdığ ; kısıtlama döneminde ise önemli ölçüde olumlu ortalama anormal getirilerle piyasanın ve yatırımcıların olumlu tepki verdiği gösterilmiştir. Böylece kısıtlamaların Hindistan hisse senedi piyasası performansı üzerinde olumlu bir etkisinin olduğu doğrulanmıştır.

AlAli (2020) çalışması DSÖ’nün Covid-19’u pandemi olarak ilan etmesinin beş büyük Asya hisse senedi piyasası üzerine etkisini 4 Mart 2019- 22 Nisan 2020 dönemi için olay etüdü yöntemi ile araştırmaktadır. Bu beş piyasa şu şekildedir: Şangay SE, Nikkei 225, Bombay SE, Hang Seng Endeksi ve Güney Kore KOSPI Bileşik Endeksi. Araştırmanın sonucu olarak pandemi ilanı öncesi ve sonrası dönemde istatistiki olarak anlamlı bir farklılık olduğu tespit edilmiştir. Büyük Asya hisse senedi piyasalarındaki getirilerin, bu ilandan büyük ölçüde negatif etkilendiği gösterilmiştir.

Rahman et al. (2021) Avustralya için iki negatif (i. Covid-19'un halk sağlığı acil durumu olarak ilan edildiği 30 Ocak 2020 ve ii. Covid-19'un pandemi olarak ilan edildiği 11 Mart 2020) ve iki pozitif (i. Avustralya Başbakanının 66,4 milyar AUD teşvik paketi açıkladığı 22 Mart 2020 ve ii. Avustralya hükümetinin 130 milyar AUD JobKeeper paketini açıkladığı 8 Nisan 2020) olayın Avustralya hisse senedi piyasası (ASX) getirilerine etkilerini olay etüdü analizi ile incelemiştir. Analiz, tüm piyasa için ve portföy düzeyinde yapılmıştır. Elde edilen sonuçlara göre Covid-19'un pandemi olarak ilan edilmesiyle ilgili ortalama CAR, firma başına ortalama 352 milyon Avustralya Doları piyasa değeri kaybına eşdeğer olan \%-4,39'dur. Ancak JobKeeper paketinin açıklanması pozitif olayının etkisi ile piyasa $\% 2,73$ oranında yeniden değer kazanmıştır. En küçük, en az karlı ve değerli portföylerin pandemiye karşı daha savunmasız olduğu tespit edilirken, boyut ve likidite kesitsel anormal getirilerin ana itici güçleri olarak ortaya konulmuştur.

Liu et al. (2020), içlerinde Japonya, ABD, Almanya, Kore, İngiltere, Singapur gibi ülkelerin bulunduğu yirmi bir lider hisse senedi piyasasının 21 Şubat 2019- 18 Mart 2020 dönemi için Covid-19'a verdiği kısa dönemli tepkileri incelemektedir. Olay etüdü ve sabit etkili panel veri yöntemi kullanılmıştır. Olay günü olarak, Çin Halk Cumhuriyeti Ulusal Sağlık ve Fitness Komisyonu üst düzey uzman grup lideri Zhong Nanshan'ın röportaj verdiği 20 Ocak 2020 alınmıştır. Sonuçlar, etkilenen başlıca ülke ve bölgelerdeki borsaların virüs salgınından sonra hızla düştüğünü göstermiştir. Ancak Asya'daki ülkelerin, diğer ülkelere kıyasla daha fazla negatif anormal getiri elde ettiğini ortaya koymuştur. Ayrıca panel sabit etki regresyonlarından elde edilen sonuca göre de yatırımcıların, Covid-19 onaylı vakalarının hisse senedi endekslerinin anormal getirileri üzerinde olumsuz etki yarattığ bulgusunu desteklediği görülmüştür. 
Özdemir, K. \& B. Hiçyılmaz (2022), "COVID-19 ve Aş1 Haberlerinin Borsa İstanbul

Sektör Endekslerine Etkisi: Bir Olay Etüdü Analizi”, Sosyoekonomi, 30(51), 471-486.

64 ülke için, Ashraf (2020) 22 Ocak 2020-17 Nisan 2020 dönemi için Covid-19’un hisse senedi piyasaları üzerindeki etkisini panel veri analizi yöntemi ile incelemiştir. Borsaların Covid-19 onaylı vakalarındaki büyümeye olumsuz tepki verdiğini, yani, teyit edilen vaka sayıları arttıkça borsa getirilerinin düştüğünü ortaya koymuştur. Bunun yanı sıra, hisse senedi piyasalarının, ölüm sayısındaki artışa kıyasla, teyit edilen vaka sayısındaki artışa daha proaktif tepki verdiğini tespit etmiştir.

Covid-19'un hisse senedi piyasaları üzerine etkisini araştıran bir diğer çalışma olan Singh et al. (2020), G20 ülkelerini kapsayan bir örneklem için olay etüdü ve panel veri analizi kullanmıştır. Zhong Nanshan'ın röportaj verdiği 20 Ocak 2020 olay günü olarak alınmıştır. 58 gün boyunca dört alt olay penceresinde istatistiksel olarak anlamlı negatif anormal getiriler tespit edilmiştir. Elde edilen negatif anormal getirilerin, gelişmiş ülkeler kadar gelişmekte olan ülkeler için de önemli olduğu bulunmuştur. Panel veri analizinden elde edilen sonuçlar ise, hisse senedi piyasalarının Covid-19'un olumsuz etkisinden kurtarıldığı yönündedir.

Bash (2020), 30 ülke için Covid-19'un her bir ülkedeki ilk kayıtlı vakasının hisse senedi getirileri üzerine etkisini çalışmıştır. Bu amaçla olay etüdü yöntemini ve çeşitli olay penceresi zaman aralıklarını kullanmıştır. Sonuçlar, Covid-19'un getiriler üzerine istatistiki olarak anlamlı ve olumsuz bir etkisinin olduğunu ortaya koymuştur.

Maneenop \& Kotcharin (2020) Covid-19'un küresel havayolu sektörü üzerindeki kısa vadeli etkisini olay etüdü ile araştırmaktadır. Bu amaçla dünya çapında listelenen 11 ülkede yer alan 52 havayolu şirketinin verileri ve ülkelerdeki ana borsa endeksi piyasa getirisini hesaplamak için kullanılmıştır. Üç önemli olay günü seçilmiştir: i) 13 Ocak 2020Çin dışında ilk bildirilen vaka, ii) 21 Şubat 2020- İtalya salgını ve iii) 11 Mart 2020- Dünya Sağlık Örgütü'nün küresel salgın salgınına ilişkin bildirisi ve Başkan Trump'ın 26 Avrupa ülkesinden yolcuları yasaklayacağını açıklaması tarihleri. Elde edilen sonuçlara göre birinci olaydan sonra az tepki, üçüncü olaydan sonra ise aşırı tepki geldiği görülmüştür. Avustralya, Kanada, İngiltere ve ABD'deki havayolu hisseleri üçüncü olay sonrası en kötü performans gösteren şirketlerdir. Bulgular, Batı ülkelerindeki yatırımcıların gelen haberlere dünyanın geri kalanından daha duyarlı olduğu yönünde yorumlanmıştır.

ABD ve Avrupa borsalarının Covid-19'a verdiği kısa dönemli tepkileri inceleyen Heyden \& Heyden (2021) olay etüdü yöntemini kullanmıştır. Veri olarak Ocak 2018'den itibaren S\&P 500 ve S\&P Europe 350'nin bileşenleri olan tüm firmaların logaritmik hisse senedi getirilerini ve literatürde yer alan standart kontrol değişkenleri kullanmışlardır. Ele aldıkları ülkelerde gerçekleşen ilk ölüm ilanına hisse senetlerinin önemli ölçüde olumsuz tepki verdiğini ortaya koymuşlardır. Ayrıca ülkelere özgü maliye politikası önlemlerinin açıklanmasının hisse senedi getirilerini olumsuz etkilediğini gösterirken, para politikası önlemlerinin piyasaları sakinleştirme potansiyeline sahip olduğunu tespit etmişlerdir. Elde edilen bir diğer sonuca göre de bu tepkiler, maddi varlıklar, likidite ve kurumsal varlıklar gibi firmaya özgü özelliklere bağlı olarak yoğunlaşır ya da azalır. 
Pandey \& Kumari (2021) olay etüdü yöntemini kullanarak Covid-19 salgınının dünyadaki gelişmiş ve gelişmekte olan ülkelerden oluşan 49 borsa endeksi üzerindeki etkilerini incelemektedir. Elde edilen sonuçlar, salgınının küresel borsaları önemli ölçüde etkilediği ve salgından en çok da Asya borsalarının etkilendiği ama Amerikan borsaları üzerindeki etkilerin hem uzun pencerede hem de kısa pencerede anlamlı olmadığını ortaya koymaktadır. Bunun yanı sıra gelişmiş piyasaların uzun vadede gelişmekte olan piyasalara göre daha sert bir şekilde etkilendiğini; ancak kısa vadede gelişmiş ülkeler üzerindeki etkinin anlamlı olmadığını göstermektedir. Ayrıca, ulusların getirdiği erken kısıtlamaların virüsün yayılmasını kontrol altına alma konusunda olumlu sonuçlar verdiğini, böylece yatırımcının güvenini yeniden inşa ettiğini ve borsa getirilerinde keskin bir tersine dönüş yaşandığını vurgulamaktadır.

Uluslararası literatürde yer alan çalışmalar genellikle Covid-19'un halk sağlığı acil durumu ilan edilişi, pandemi olarak ilan edilişi, ülkedeki ilk vakanın ve ilk ölüm vakasının tarihleri ile kısıtlama tarihleri gibi virüsün çıkışına yönelik genel olayların etkilerini araştırmaktadır. Bu çalışmalardan elde edilen sonuçlar özellikle sektör düzeyinde getirilere etkilerin farklılaşabileceğini göstermektedir. Uluslararası literatürden ayrı olarak Türkiye'de yapılan çalışmaların özeti ise Tablo 1'de sunulmuştur.

Tablo: 1

Türkiye için Yapılan Çalışmaların Özeti

\begin{tabular}{|c|c|c|c|c|}
\hline Çalışma & Değişken(ler) & Periyod & Yöntem & Sonuç \\
\hline $\begin{array}{l}\text { Kılıç } \\
(2020)\end{array}$ & Borsa İstanbul sektör endeksleri & $\begin{array}{l}02.01 .2018- \\
30.04 .2020\end{array}$ & Olay Etüdü & $\begin{array}{l}\text { Çin'de yaşanan ilk ölüm ve DSÖ’nün Covid-19 } \\
\text { tanımlaması anormal getiriye sebep olmamıştır. } \\
\text { DSÖ'nün pandemi ilanı ve Türkiye'de ilk vakanın } \\
\text { görülmesi sektörlerin çoğunda negatif anormal } \\
\text { getiriye sebep olmuştur. Ticaret, mali ve banka } \\
\text { sektörlerinde pozitif anormal getiri tespit edilmiştir. } \\
\text { İlk sokağa çıkma kısıtlaması anormal getiriye sebep } \\
\text { olmamıştır. }\end{array}$ \\
\hline $\begin{array}{l}\text { Keleş } \\
(2020)\end{array}$ & $\begin{array}{l}\text { BIST 30'da yer alan firmaların fiyat } \\
\text { verisi }\end{array}$ & $\begin{array}{l}02.03 .2020- \\
29.04 .2020\end{array}$ & Olay Etüdü & $\begin{array}{l}\text { İlk vaka sonrası } 11 \text { Mart'ta düşüşs tespit edilmişstir. } \\
\text { Ancak istatistiki olarak anlamlı değildir. } 12 \text { Mart'ta } \\
\text { düšşs devam etmiştir ve anlamlıdır. } 12 \text { Mart'ta } \\
\text { eğitime ara verildikten sonraki gün } 13 \text { Mart'ta piyasa } \\
\text { önlemlere olumlu tepki vermiştir. } \\
\text { Ölüm sayısının } 1000 \text { 'in üzerine çıkması negatif tepki } \\
\text { yaratmıştır. } \\
\text { Otomobiller ve Bileşenleri grubu ile Taşımacılık } \\
\text { grubu, Covid-19'un yarattığı finansal iniş çıkışlardan } \\
\text { incelenen diğer sanayi gruplarına göre daha çok } \\
\text { etkilenmiştir. Ara ve sermaye malları gruplarının } \\
\text { tepkileri snırlı kalmıstır. }\end{array}$ \\
\hline $\begin{array}{c}\text { Göker vd. } \\
\text { (2020) }\end{array}$ & BIST' te yer alan 26 sektör endeksi & $\begin{array}{l}02.01 .2019- \\
09.04 .2020\end{array}$ & Olay Etüdü & $\begin{array}{l}11 \text { Mart } 2020 \text { günü spor, turizm ve yatırım ortaklı̆̆ı } \\
\text { sektörleri negatif kümülatif anormal getiri almışken, } \\
\text { yiyecek-içecek, toptan ve perakende sektörleri } \\
\text { pozitif kümülatif anormal getiri almıştır. } \\
\text { Genel olarak spor, turizm ve tekstil sektörleri Covid- } \\
\text { 19'dan en çok negatif etkilenen sektörler olmuştur. }\end{array}$ \\
\hline
\end{tabular}


Özdemir, K. \& B. Hiçyılmaz (2022), "COVID-19 ve Aş1 Haberlerinin Borsa İstanbul Sektör Endekslerine Etkisi: Bir Olay Etüdü Analizi”, Sosyoekonomi, 30(51), 471-486.

\begin{tabular}{|c|c|c|c|c|}
\hline $\begin{array}{l}\text { Çetin } \\
(2020)\end{array}$ & $\begin{array}{l}\text { Açıklanan değişkenler: BIST } 100 \\
\text { kapanış fiyatı, açılış fiyatı, en düşük } \\
\text { fiyatı, en yüksek fiyatı ve genel } \\
\text { ekonomi faaliyetlerinin düzeyi } \\
\text { Açıklayıcı değişkenler: Sokağa çıkma } \\
\text { kısıtlaması uygulanan gün sayısı, yurt } \\
\text { içi ve yurt dışı seyahat kısıtlaması } \\
\text { uygulanan gün sayıları, para politikası } \\
\text { kararları, kamu harcamaları, yeni vaka } \\
\text { sayısı }\end{array}$ & $\begin{array}{l}23.03 .2020- \\
24.04 .2020\end{array}$ & $\begin{array}{l}\text { En Küçük } \\
\text { Kareler }\end{array}$ & $\begin{array}{l}\text { Sokağa çıkma kısıtlaması genel ekonomi } \\
\text { faaliyetlerini negatif etkilemiştir. } \\
\text { Yurt içi seyahat kısıtlaması BIST } 100 \text { kapanış } \\
\text { fiyatını ve genel ekonomi faaliyetlerini pozitif } \\
\text { etkilemiştir. } \\
\text { Yurt dışı seyahat kısıtlaması BIST } 100 \text { kapanış } \\
\text { fiyatını, en düşük fiyatını ve genel ekonomi } \\
\text { faaliyetlerini negatif etkilemiştir. } \\
\text { Para politikası kararları tüm açıklanan değişkenleri } \\
\text { pozitif etkilemiştir. } \\
\text { Kamu harcamaları tüm açıklanan değişkenleri pozitif } \\
\text { etkilemiştir. } \\
\text { Yeni vaka sayısı, genel ekonomi faaliyetlerinin } \\
\text { düzeyini etkilememiş, diğer tüm açıklanan } \\
\text { değișkenleri pozitif etkilemiștir. }\end{array}$ \\
\hline $\begin{array}{c}\text { Peker \& } \\
\text { Demirhan } \\
(2020)\end{array}$ & $\begin{array}{l}\text { BIST } 100 \text { hisse senetlerinin sektörel } \\
\text { bazdaki getiri oranları ve volatilite }\end{array}$ & $\begin{array}{l}\text { 1) } 7.01 .2020 \\
\text { (öncesi ve sonras1 } \\
5,10,20,30,45 \\
\text { gün) } \\
\text { 2) } 11.03 .2020 \\
\text { (öncesi ve sonras1 } \\
5 \text { ve } 10 \text { gün) } \\
\text { 3) } 21.03 .2020 \\
\text { (öncesi ve sonras1 } \\
5 \text { ve } 10 \text { gün) }\end{array}$ & GARCH & $\begin{array}{l}\text { Küresel salgın, Borsa İstanbul sektörlerinin getirileri } \\
\text { ve volatiliteyi etkilemiştir. } \\
\text { Çin'de salgının başladığı } 7 \text { Ocak'ta Holding ve mali } \\
\text { hizmetler gibi küresel ticaretin gelişmesine bağlı } \\
\text { sektörlerin getirileri düşmüştür. 7 Ocak'tan sonra } \\
\text { düşük teknolojili sektörlerin (gıda, tekstil gibi) } \\
\text { getirileri artmış, diğerlerinin ise sabit kalmıştır. } \\
\text { Düşük teknolojili sektörler, salgının Türkiye'de } \\
\text { görülmesinden olumsuz etkilenmiştir. 21 Mart'ta } \\
\text { alı̈nan önlemlerin açıklanması ile salgın öncesi } \\
\text { düzeyine gelmiştir. Ulaştırma, bankacıllı ve sigorta } \\
\text { gibi ticarete konu olmayan sektörlerin ise eski } \\
\text { düzeylerine gelemediği tespit edilmiştir. }\end{array}$ \\
\hline $\begin{array}{l}\text { Gülhan } \\
(2020)\end{array}$ & $\begin{array}{l}\text { BIST } 100 \text { Endeksi, Covid-19 Ölüm } \\
\text { Oranı, Dolar Kuru, Enfeksiyon } \\
\text { Hastalıkları ile Sermaye Piyasaları } \\
\text { Oynaklık Endeksi, MSCI ve VIX } \\
\text { indeksi }\end{array}$ & $\begin{array}{l}31.12 .2019- \\
28.05 .2020\end{array}$ & $\begin{array}{c}\text { Robust En } \\
\text { Küçük Kareler } \\
\text { ve Hata } \\
\text { Düzeltme Modeli }\end{array}$ & $\begin{array}{l}\text { Kısa dönemde, borsa endeksi ve değişkenler arasında } \\
\text { anlamlı ilişsiler tespit edilmiştir. Borsa endeksi ile } \\
\text { ölüm oranı, dolar kuru ve VIX arasında negatif; } \\
\text { enfeksiyon hastalıkları ile sermaye piyasaları } \\
\text { oynaklık endeksi ve MSCI arasında pozitif ilişki } \\
\text { bulunmuştur. } \\
\text { Uzun dönemde, borsa endeksi ve ölümlülük oranı ve } \\
\text { MSCI arasında anlamlı ve sırasıyla negatif ve pozitif } \\
\text { ilişkiler tespit edilmiştir. }\end{array}$ \\
\hline $\begin{array}{l}\text { Öztürk } \\
\text { vd. } \\
(2020)\end{array}$ & $\begin{array}{l}\text { BIST Sektör Fiyat Endeksleri (21 alt } \\
\text { sektör ve } 7 \text { ana sektör), Covid-19 Vaka } \\
\text { Sayısı, CDS Risk Primi, VIX Volatilite } \\
\text { İndeksi }\end{array}$ & $\begin{array}{l}02.01 .2020- \\
15.04 .2020\end{array}$ & $\begin{array}{c}\text { Sabit Etkiler } \\
\text { Tahmin Metodu }\end{array}$ & $\begin{array}{l}\text { Sektör endeksleri, Dünya ve Avrupa vaka } \\
\text { sayılarından çok Türkiye'deki vaka sayılarından } \\
\text { etkilenmiştir. Metal ürünleri ve makine sektörleri en } \\
\text { çok etkilenen sektörler olmuştur. Spor, bankacılık ve } \\
\text { sigortacılık da bu endüstrileri takip etmektedir. } \\
\text { Yiyecek-içecek, toptan-perakende satış ve } \\
\text { gayrimenkul yatırım sektörleri salgından en az } \\
\text { etkilenen sektörlerdir. }\end{array}$ \\
\hline $\begin{array}{l}\text { Tayar vd. } \\
(2020)\end{array}$ & $\begin{array}{l}\text { BIST Temel Sektör Verilerinde Bir Gün } \\
\text { Önceye Göre Meydana Gelen Değişim } \\
\text { Oranı ve Aktif Covid-19 Sayısında Bir } \\
\text { Gün Önceye Göre Meydana Gelen } \\
\text { Değişim Oranı }\end{array}$ & $\begin{array}{l}17.03 .2020- \\
29.04 .2020\end{array}$ & $\begin{array}{c}\text { En Küçük } \\
\text { Kareler Yöntemi }\end{array}$ & $\begin{array}{l}\text { Covid-19 aktif vaka sayısındaki değişim sektörel } \\
\text { endekslerden elektrik, ulaşım, finansal kuruluşlar, } \\
\text { teknoloji ve sanayi üzerine negatif ve istatistiki } \\
\text { olarak anlamlı etkiye sahiptir. } \\
\text { Gıda, ticaret, tekstil, turizm ve hizmet sektörlerine } \\
\text { etkisi istatistiki olarak anlamlı değildir. }\end{array}$ \\
\hline $\begin{array}{l}\text { Çoban vd. } \\
(2020)\end{array}$ & $\begin{array}{l}\text { BİST100 Endeksi, Covid-19 Günlük } \\
\text { Vaka Sayısı, Altının Gram Fiyatı, CDS } \\
\text { Risk Pirimi, Euro ve Dolar Döviz Kuru }\end{array}$ & $\begin{array}{l}16.03 .2020- \\
21.08 .2020\end{array}$ & $\begin{array}{l}\text { Toda-Yamamoto } \\
\text { Nedensellik Testi }\end{array}$ & $\begin{array}{l}\text { Covid-19 vaka sayılarından Euro ve Dolar kuruna } \\
\text { doğru bir nedensellik ilişkisi tespit edilmiştir. }\end{array}$ \\
\hline $\begin{array}{l}\text { Saka-Ilgin } \\
\text { \& Sarı } \\
(2020)\end{array}$ & $\begin{array}{l}6 \text { ülkenin hisse senedi kapanış fiyatı } \\
\text { verileri } \\
\text { (Türkiye için BIST100 endeksi kapanış } \\
\text { fiyatları) } \\
\text { Ülkelerdeki Covid-19 günlük toplam } \\
\text { vaka sayıları ve toplam ölüm sayıları }\end{array}$ & $\begin{array}{l}18.02 .2020- \\
30.09 .2020\end{array}$ & $\begin{array}{l}\text { Toda-Yamamoto } \\
\text { Nedensellik Testi }\end{array}$ & $\begin{array}{l}\text { Türkiye için elde edilen sonuca göre toplam vaka ve } \\
\text { ölüm sayılarından endekse doğru nedensellik ilişkisi } \\
\text { tespit edilmiştir. } \\
\text { Analiz edilen diğer ülkeler olan ABD, Hindistan, } \\
\text { Brezilya, Rusya, Kolombiya için de aynı sonuç elde } \\
\text { edilmiştir. }\end{array}$ \\
\hline $\begin{array}{l}\text { Yildız- } \\
\text { Contuk } \\
(2021)\end{array}$ & $\begin{array}{l}\text { BIST Toplam İşlem Hacmi, Covid-19 } \\
\text { pozitif vaka sayısı }\end{array}$ & $\begin{array}{l}11.03 .2020- \\
16.06 .2020\end{array}$ & ARDL Yöntemi & $\begin{array}{l}\text { Covid-19 pozitif vakalar ile borsa işlem hacmi } \\
\text { arasında kısa vadede negatif bir ilişki tespit } \\
\text { edilmiştir. Vakalardaki artış kısa vadede borsayı } \\
\text { negatif etkilemiştir. } \\
\text { Uzun dönemde, iki değişken arasında pozitif bir } \\
\text { ilişki tespit edilmiştir. }\end{array}$ \\
\hline
\end{tabular}

Türkiye için literatürden görülebileceği üzere hisse senedi getirilerine ve sektör endekslerine olan etkiler hem farklı yöntemler hem de farklı olay günleri baz alınarak araştırılmıştır. Uluslararası literatür ile paralel olarak, Türkiye için de anormal getiri/kayıp 
sonuçlarının sektörel düzeyde farklılaştığı görülmektedir (Kılıç, 2020; Göker vd., 2020). Bu çalışmada önceki çalışmalarla ortak olan 11 Mart 2020 tarihinden farklı olarak, bilindiği kadarıyla etkileri daha önce olay etüdü yöntemiyle incelenmemiş olan Türkiye'de ilk ölüm vakası ve CoronaVac aşısının ilk partisinin Türkiye'ye geliş tarihlerinin sektör endeksleri üzerine etkilerinin analiz edilmesi ve bu alandaki boşluğun kapatılması amaçlanmaktadır.

\section{Veri ve Yöntem}

Etkin piyasalar hipotezine dayanan olay etüdü, belirli bir tarihte gerçekleşen olayın firmaların hisse senedi üzerinde anormal getirilere neden olup olmadığını belirlemede kullanılan yöntemlerden birisidir. Bu özelliği olay etüdü yöntemini güçlü kılan en önemli unsurdur. Etkin piyasalar hipotezine göre yatırımcıların piyasaya düşen haberleri dikkate aldığ1 varsayılmaktadır (Fama, 1970: 414). Eğer haber yatırımcılar tarafindan olumlu algılanırsa pozitif hisse senedi getirileri beklenirken, piyasanın olumsuz bir haber olarak değerlendirmesi durumunda ise negatif hisse senedi getirileri oluşması beklenmektedir. Dolayısıyla, hisse senetlerinin genel seyrini gösteren endekslerde de olay etüdü yöntemiyle anormal getirilerin ortaya çıkıp çıkmadığın tespiti yapılabilir ve bu sayede hangi sektörün nasıl etkilendiğine ilişkin fikir edinilebilmektedir (Schwert, 1981). Bu kapsamda 11 Mart 2020 DSÖ tarafindan pandemi ilanı ve Türkiye'de ilk vaka, 17 Mart 2020 Covid-19 kaynaklı Türkiye'de ilk ölüm vakası ve 30 Aralık 2020 Türkiye'ye anlaşması yapılan ilk parti aşının gelmesi haberinin Tablo 2'de belirtilen 23 Borsa İstanbul sektör endeksi üzerinde etkisi araştırılmıştır ve kullanılan veriler Foreks FxPlus programından alınmıştır.

Tablo: 2

\section{Borsa İstanbul Sektör Endeksleri}

\begin{tabular}{|c|c|c|c|}
\hline ENDEKS KODU & ENDEKS ADI & ENDEKS KODU & ENDEKS ADI \\
\hline XBANK & Banka & XSGRT & Sigorta \\
\hline XBLSM & Bilişim & XSPOR & Spor \\
\hline XELKT & Elektrik & XTAST & Taş, Toprak \\
\hline XFINK & Finansal Kiralama, Faktöring & XTCRT & Ticaret \\
\hline XGIDA & Gida, İçecek & XTEKS & Tekstil, Deri \\
\hline XGMYO & Gayri Menkul Yatırım Ortaklı̆ı̆ & XTRZM & Turizm \\
\hline XHOLD & Holding ve Yatırım & XULAS & Ulaştırma \\
\hline XILTM & İletişim & XUHIZ & Hizmetler \\
\hline XKAGT & Orman, Kâğıt, Basım & XUMAL & Mali \\
\hline XKMYA & Kimya, Petrol, Plastik & XUSIN & Snai \\
\hline XMANA & Metal Ana & XUTEK & Teknoloji \\
\hline XMESY & Metal Eşya, Makina & \\
\hline
\end{tabular}

Kaynak: <https://www.kap.org.tr/tr/Endeksler>, 23.04.2021.

Olay etüdü analizinde aşırı getiriler hesaplanırken genellikle kullanılan üç temel model bulunmaktadır: Ortalama düzeltilmiş getiri modeli, piyasaya göre ayarlanmış getiri modeli ve piyasa modeli. Dyckman et al., (1984: 28-29)'ne göre üç modelin anormal getirinin varlığını doğru bir şekilde tespit etme yetenekleri açısından, piyasa modelinin küçük de olsa tercih edilebilirliği bulunsa bile, modeller benzerdir. Bu fark istatistiksel olarak anlamlı olmakla birlikte önemli bulunmamıştır. Bu çalışmada Chen \& Siems, (2004) ve Brown \& Warner, (1985) tarafından kullanılan ortalama düzeltilmiş getiriler yöntemi kullanılmıştır. 


$$
A R_{t}=R_{t}-\bar{R}
$$

Formülde $A R_{t}$ anormal getiriyi, $t$ alt indisi zamanı temsil ederken, $\bar{R}$ ise tahmin penceresi $(-110,-11)^{1}$ için ilgili sektör endekslerinin ortalama getirisini ifade etmektedir ve şu şekilde hesaplanmaktadır:

$$
\bar{R}=\frac{1}{100} \sum_{t=-110}^{-11} R_{t}
$$

Elde edilen anormal getirilerin istatistiki olarak anlamlılığını test etmek için Brown \& Warner, (1985) tarafından kullanılan standartlaştırılmış anormal getiriler yöntemi kullanılmıştır.

$$
\begin{aligned}
& S A R_{t}=\frac{A R_{t}}{S D\left(A R_{t}\right)} \\
& \text { burada } S D\left(A R_{t}\right)=\sqrt{\frac{1}{T_{0}-1} \sum_{t=1}^{T_{0}} A R_{t}^{2}}
\end{aligned}
$$

Piyasada olay günü anormal getirinin ortaya çıkıp çıkmadı̆̆ının tespitinin ardından ilgili olayın etkisinin devam edip etmediğini incelemek için kümülatif anormal getiri (CAR6 ve CAR11) hesaplanmıştır. Sonuçların istatistiki olarak anlamlılığının belirlenmesi için elde edilen CAR standart sapma değerlerine bölünerek t-istatistiği değerleri elde edilmiştir.

$$
\begin{aligned}
& C A R 6=\sum_{t=0}^{5} A R_{t} \\
& t_{\text {CAR6 }_{t}}=\frac{\text { CAR6 }_{t}}{S D\left(\text { CAR6 }_{t}\right)} \\
& \text { CAR11 }=\sum_{t=0}^{10} A R_{t} \\
& t_{C A R 11_{t}}=\frac{\text { CAR } 11_{t}}{S D\left(C A R 11_{t}\right)}
\end{aligned}
$$

\section{Bulgular}

11 Mart 2020, 17 Mart 2020 ve 30 Aralık 2020 olay gününün etkilerinin incelendiği analizden elde edilen sonuçlar Tablo 3,4,5'te sunulmuştur.

11.03.2020 tarihli birinci olayın etkisine Tablo 3’ten bakıldığında, olay gününde 4 pozitif ve 19 negatif anormal getiri (AR) tespit edilmiştir. Bu anormal getirilerden 15 'i

1 Uygulamada tahmin penceresi olarak 100 gün yerine 20 gün tercih eden çallşmalar (Chen \& Siems, 2004; Aksoy, 2014) ve 230-250 gün arası tercih eden çalışmalar (Brown \& Warner, 1985; Keleş, 2020; Göker vd., 2020) bulunmaktadır. Bu çalışmada 20 gün alınmamasının nedeni, 20 gün içerisinde gerçekleşmiş ve piyasanın aşırı tepki vermesine sebep olacak anormal olayın ortalama getiriyi, 100 günlük getiriler kullanılarak hesaplanacak ortalamaya göre daha çok etkileyecek ve kisa tahmin penceresi neticesinde sonucun yanlı bulunacak (He et al., 2020: 2202) olmasıdir. Aynı şekilde, uygulamada tercih edilen 230-239-250 vb. alınmamasının sebebi de He et al. (2020: 2202) tarafindan da açılandı̆̆ üzere daha uzun tahmin penceresinin tahmin yapısını değiştirebilecek olmasıdır. Xiong et al. (2020), Kılıç (2020), Sun et al. (2021) çalışmaları takip edilerek tahmin penceresi 100 gün olarak alınmıştır. 
istatistiki olarak anlamlıdır. Bunların 2'si (XTCRT, XUHIZ) pozitif anormal getiri ve 13'ü (XBLSM, XELKT, XFINK, XGMYO, XHOLD, XKAGT, XMANA, XMESY, XSPOR, XTEKS, XTRZM, XULAS, XUSIN) negatif anormal getiriye sahiptir. En fazla getiri ve kayıp sırasıyla ticaret ve spor endekslerinde yaşanmıştır. Ticaret endeksi $\% 8$ pozitif anormal getiri sağlarken, spor endeksinde -\%10 anormal kayba neden olmuştur.

Tablo: 3

\subsubsection{0 için Anormal Getiri, Kümülatif Anormal Getiri ve t İstatistiği}

\begin{tabular}{|c|c|c|c|c|c|c|}
\hline ENDEKS & AR & SAR & CAR $_{6}$ & $t_{\text {CAR6 }}$ & CAR $_{11}$ & tCAR11 $_{1}$ \\
\hline XBANK & 0,0050 & 0,2690 & $-0,13653$ & $-1,60579$ & $-0,1791 * *$ & $-2,4335$ \\
\hline XBLSM & $-0,0595 * *$ & $-2,4943$ & $-0,39114 *$ & $-2,41867$ & $-0,1611$ & $-1,3654$ \\
\hline XELKT & $-0,0580$ **** & $-3,0698$ & $-0,19783$ & $-1,97494$ & $-0,1840^{* *}$ & $-2,3790$ \\
\hline XFINK & $-0,0519^{*}$ & $-1,8035$ & $-0,07409$ & $-0,31541$ & 0,0192 & 0,1099 \\
\hline XGIDA & $-0,0007$ & $-0,0432$ & $-0,21208^{*}$ & $-2,46206$ & $-0,0894$ & $-1,3872$ \\
\hline XGMYO & $-0,0398 * *$ & $-2,3985$ & $-0,22677$ & $-1,41928$ & $-0,1841$ & $-1,5455$ \\
\hline XHOLD & $-0,0307^{* * *}$ & $-2,3484$ & $-0,19933$ & $-1,77958$ & $-0,1442$ & $-1,6773$ \\
\hline XILTM & 0,0206 & 1,3414 & $-0,10445$ & $-1,38951$ & $-0,0382$ & $-0,6214$ \\
\hline XKAGT & $-0,0390^{*}$ & $-1,8362$ & $-0,26759$ & $-1,57615$ & $-0,1731$ & $-1,4190$ \\
\hline XKMYA & $-0,0198$ & $-1,5984$ & $-0,2211$ & $-1,64019$ & $-0,1075$ & $-1,0908$ \\
\hline XMANA & $-0,0334 * *$ & $-2,3439$ & $-0,17359 * *$ & $-2,85898$ & $-0,1545^{* *}$ & $-3,0148$ \\
\hline XMESY & $-0,0247^{*} * *$ & $-2,0108$ & $-0,30422 * *$ & $-2,58545$ & $-0,3075 * * *$ & $-3,7477$ \\
\hline XSGRT & $-0,0096$ & $-0,9825$ & $-0,2183^{* *}$ & $-3,67626$ & $-0,1880^{* * * *}$ & $-3,9890$ \\
\hline XSPOR & $-0,0951 * *$ & $-2,4039$ & $-0,46959$ & $-1,53806$ & $-0,4931^{*}$ & $-2,2002$ \\
\hline XTAST & $-0,0227$ & $-1,2900$ & $-0,20005$ & $-1,32702$ & $-0,1770$ & $-1,6187$ \\
\hline XTCRT & $0,0762 * * *$ & 7,2424 & $-0,0821$ & $-1,5405$ & 0,0068 & 0,1849 \\
\hline XTEKS & $-0,0569$ *** & $-3,1825$ & $-0,32337$ & $-1,56763$ & $-0,2885^{*}$ & $-1,9838$ \\
\hline XTRZM & $-0,0774 * * * *$ & $-3,2985$ & $-0,3966$ & $-1,6177$ & $-0,4151 * *$ & $-2,2784$ \\
\hline XULAS & $-0,0429 * *$ & $-2,0920$ & $-0,26288$ & $-0,97247$ & $-0,1737$ & $-0,8693$ \\
\hline XUHIZ & $0,0212 *$ & 1,8642 & $-0,14104$ & $-1,87435$ & $-0,0700$ & $-1,1437$ \\
\hline XUMAL & $-0,0111$ & $-0,7218$ & $-0,1657$ & $-1,64617$ & $-0,1672^{*}$ & $-2,0615$ \\
\hline XUSIN & $-0,0222^{*}$ & $-1,9766$ & $-0,22564$ & $-1,97369$ & $-0,1577^{*}$ & $-1,8806$ \\
\hline XUTEK & $-0,0140$ & $-0,7212$ & $-0,24935^{*}$ & $-2,34025$ & $-0,1427$ & $-1,7835$ \\
\hline
\end{tabular}

Not: *, ** ve *** sirastyla \%10, \%5 ve \%1 anlamlllk düzeyini temsil etmektedir. SAR için to9, 0,005=2,626, t99.

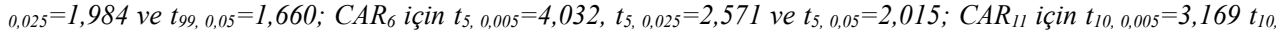
$0,025=2,228$ ve $t_{10,0,05}=1,812$.

Tablo 3'te raporlanan kümülatif anormal getirilere bakıldığında, 23 negatif CAR6'dan 6 sektör endeksinin değerinin (XBLSM, XGIDA, XMANA, XMESY, XSGRT, XUTEK) istatistiki olarak anlamlı olduğu görülmüştür. En fazla kümülatif anormal kayıp yaşayan \%39 ile bilişim sektör endeksidir. En düşük kayıp yaşayan ise \%21 ile gıda endeksidir. $\mathrm{CAR}_{11}$ değerleri incelendiğinde ise 2 pozitif ve 21 negatif sonuçtan sadece 10 sektörün (XBANK, XELKT, XMANA, XMESY, XSGRT, XSPOR, XTEKS, XTRZM, XUMAL, XUSIN) negatif kümülatif anormal getirisinin istatistiki olarak anlamlı olduğu sonucuna varılmıştır. Spor endeksi -\%49, turizm endeksi -\%41 kümülatif anormal kayıp ile en çok etkilenen sektör endeksleri olmuşlardır. En düşük kümülatif anormal kayıp ise -\%15 ile metal ana sanayi endeksinde gerçekleşmiştir.

17.03.2020 olay gününün etkisine Tablo 4'ten bakıldığında, toplamda ilk olay gününde olduğu gibi 4 pozitif ve 19 negatif anormal getiri (AR) tespit edilmiştir. Ancak, bunlardan sadece 2 pozitif (XFINK, XILTM) ve 14 negatif (XBLSM, XELKT, XGIDA, XGMYO, XHOLD, XKMYA, XMESY, XSGRT, XTAST, XTCRT, XTRZM, XULAS, XUSIN, XUTEK) anormal getirinin istatistiki olarak anlamlı olduğu görülmüştür. Olay günü finansal kiralama endeksi $\% 5$ pozitif anormal getiri elde ederken, turizm sektör endeksi 
Özdemir, K. \& B. Hiçyılmaz (2022), "COVID-19 ve Aş1 Haberlerinin Borsa İstanbul

Sektör Endekslerine Etkisi: Bir Olay Etüdü Analizi”, Sosyoekonomi, 30(51), 471-486.

yaklaşık -\%7 anormal kayıp yaşamıştır. CAR değerleri incelendiğinde olayın istatistiki olarak anlamlı kümülatif anormal getirisi olmadığı belirlenmiştir.

Tablo: 4

17.03.2020 için Anormal Getiri, Kümülatif Anormal Getiri ve t İstatistiği

\begin{tabular}{|c|c|c|c|c|c|c|}
\hline ENDEKS & $\mathbf{A R}$ & SAR & CAR $_{6}$ & $\mathbf{t}_{\mathrm{CAR6}}$ & $\mathrm{CAR}_{11}$ & $t_{\text {CAR11 }}$ \\
\hline XBANK & 0,0235 & 1,1831 & $-0,0377$ & $-0,36709$ & $-0,0258$ & $-0,3232$ \\
\hline XBLSM & $-0,0457^{*}$ & $-1,8705$ & 0,097887 & 0,244374 & 0,1873 & 0,6954 \\
\hline XELKT & $-0,0352 *$ & $-1,7636$ & $-0,02308$ & $-0,09661$ & $-0,0027$ & $-0,0164$ \\
\hline XFINK & $0,0537^{*}$ & 1,7748 & 0,246643 & 0,689986 & 0,1751 & 0,7190 \\
\hline XGIDA & $-0,0482^{* * * * *}$ & $-3,0658$ & 0,035104 & 0,195252 & 0,0267 & 0,2202 \\
\hline XGMYO & $-0,0364 * *$ & $-2,0090$ & 0,006531 & 0,022974 & 0,0468 & 0,2431 \\
\hline XHOLD & $-0,0255^{*}$ & $-1,6994$ & $-0,00617$ & $-0,03353$ & 0,0258 & 0,2060 \\
\hline XILTM & $0,0337 * *$ & 2,1914 & 0,10029 & 0,90258 & 0,0313 & 0,3808 \\
\hline XKAGT & $-0,0226$ & $-1,0200$ & 0,001191 & 0,00346 & 0,1788 & 0,7615 \\
\hline XKMYA & $-0,0524 * * * *$ & $-4,0345$ & 0,005548 & 0,027765 & 0,0526 & 0,3843 \\
\hline XMANA & $-0,0160$ & $-1,0324$ & 0,044765 & 0,358861 & $-0,0045$ & $-0,0525$ \\
\hline XMESY & $-0,0494$ **** & $-3,8166$ & $-0,08725$ & $-0,32028$ & $-0,0755$ & $-0,4078$ \\
\hline XSGRT & $-0,0416^{* * * *}$ & $-3,8761$ & $-0,00939$ & $-0,0735$ & $-0,0421$ & $-0,4874$ \\
\hline XSPOR & $-0,0654$ & $-1,6204$ & $-0,21745$ & $-0,36246$ & 0,0941 & 0,2322 \\
\hline XTAST & $-0,0534 * * * *$ & $-2,8863$ & $-0,00415$ & $-0,01581$ & 0,0676 & 0,3784 \\
\hline XTCRT & $-0,0384^{*} * * *$ & $-3,5347$ & 0,122428 & 1,766308 & 0,0871 & 1,3628 \\
\hline XTEKS & $-0,0390 * *$ & $-2,1416$ & $-0,04818$ & $-0,12199$ & 0,0334 & 0,1238 \\
\hline XTRZM & $-0,0679$ **** & $-2,6547$ & $-0,12241$ & $-0,28103$ & 0,0298 & 0,1011 \\
\hline XULAS & $-0,0472 * *$ & $-2,0857$ & $-0,03984$ & $-0,12234$ & 0,0940 & 0,4208 \\
\hline XUHIZ & $-0,0185$ & $-1,5230$ & 0,069282 & 0,542824 & 0,0643 & 0,7215 \\
\hline XUMAL & 0,0016 & 0,0951 & $-0,02115$ & $-0,14435$ & $-0,0017$ & $-0,0167$ \\
\hline XUSIN & $-0,0409^{* * * *}$ & $-3,3502$ & 0,004859 & 0,023492 & 0,0195 & 0,1390 \\
\hline XUTEK & $-0,0457$ ** & $-2,3023$ & 0,00845 & 0,034806 & 0,0436 & 0,2637 \\
\hline
\end{tabular}

Not: *, **ve *** sirasiyla \%10, \%5 ve \%1 anlamlılık düzeyini temsil etmektedir. SAR için to9, 0,005 $=2,626, t_{90}$ ${ }_{0,025}=1,984$ ve $t_{99,0,05}=1,660 ; C A R_{6}$ için $t_{5,0,005}=4,032, t_{5,0,025}=2,571$ ve $t_{5,0,05}=2,015$; $C A R_{11}$ için $t_{10,0,005}=3,169 t_{10}$, $0,025=2,228$ ve $t_{10,0,05}=1,812$.

Tablo: 5

\subsubsection{0 için Anormal Getiri, Kümülatif Anormal Getiri ve t İstatistiği}

\begin{tabular}{|c|c|c|c|c|c|c|}
\hline ENDEKS & $\mathbf{A R}$ & SAR & $\mathrm{CAR}_{6}$ & $\mathbf{t}_{\mathrm{CAR6}}$ & CAR $_{11}$ & $t_{\text {CAR11 }}$ \\
\hline XBANK & 0,0261 & 1,0672 & $0,061149 * * *$ & 15,18661 & $0,0265^{* * * *}$ & 4,3705 \\
\hline XBLSM & 0,0031 & 0,1674 & 0,021502 & 0,360658 & 0,0651 & 1,5243 \\
\hline XELKT & 0,0062 & 0,2821 & $0,040224 * *$ & 3,754366 & 0,0076 & 0,6642 \\
\hline XFINK & 0,0023 & 0,1021 & 0,023188 & 0,835119 & 0,0049 & 0,2454 \\
\hline XGIDA & 0,0147 & 0,8829 & 0,020057 & 1,295341 & $0,0736^{* * * *}$ & 5,7880 \\
\hline XGMYO & $-0,0059$ & $-0,3091$ & $0,078868 * * *$ & 5,388011 & $0,0645^{* * * *}$ & 3,7339 \\
\hline XHOLD & 0,0066 & 0,3899 & 0,024736 & 1,46133 & $0,0479 * * *$ & 3,7434 \\
\hline XILTM & 0,0156 & 0,7870 & 0,047237 & 1,434923 & $0,0490 *$ & 1,8232 \\
\hline XKAGT & $-0,0218$ & $-0,9394$ & $-0,0932$ & $-0,63976$ & $-0,1067$ & $-0,9214$ \\
\hline XKMYA & 0,0109 & 0,6377 & 0,020256 & 0,531523 & 0,0112 & 0,3749 \\
\hline XMANA & 0,0074 & 0,3722 & $-0,03027$ & $-1,0624$ & $-0,0179$ & $-0,5485$ \\
\hline XMESY & $-0,0078$ & $-0,4128$ & 0,044769 & 1,7907 & $0,0936^{* * * *}$ & 3,7009 \\
\hline XSGRT & 0,0150 & 0,9136 & $0,067921 * *$ & 2,689601 & $0,0701 * * *$ & 3,8974 \\
\hline XSPOR & $-0,0070$ & $-0,1707$ & 0,070563 & 0,957434 & 0,0852 & 1,5319 \\
\hline XTAST & 0,0230 & 1,0061 & 0,045617 & 1,86574 & $0,0401 *$ & 1,9428 \\
\hline XTCRT & 0,0122 & 0,8084 & 0,016719 & 0,463576 & 0,0244 & 0,9388 \\
\hline XTEKS & 0,0024 & 0,1329 & 0,002469 & 0,3172 & 0,0510 *** & 4,7649 \\
\hline XTRZM & 0,0147 & 0,5432 & $0,117664 * * *$ & 7,559239 & 0,1759 *** & 8,6095 \\
\hline XULAS & 0,0100 & 0,3900 & $-0,0118$ & $-0,26457$ & 0,0226 & 0,5885 \\
\hline XUHIZ & 0,0102 & 0,7646 & 0,031475 & 1,109819 & $0,0408 *$ & 2,0191 \\
\hline XUMAL & 0,0138 & 0,7356 & $0,04723 * * *$ & 4,546067 & 0,0395 *** & 4,5466 \\
\hline XUSIN & 0,0063 & 0,4341 & 0,014843 & 1,377047 & $0,0353 *$ & 2,0644 \\
\hline XUTEK & 0,0193 & 0,9144 & 0,042694 & 1,489486 & $0,0467 * *$ & 2,2546 \\
\hline
\end{tabular}

Not: *, **ve *** siraslyla \%10, \%5 ve \%1 anlamlılık düzeyini temsil etmektedir. SAR için t99, 0,005 $=2,626, t_{99}$, ${ }_{0,025}=1,984$ ve $t_{99,0,05}=1,660 ; C A R_{6}$ için $t_{5,0,005}=4,032, t_{5,0,025}=2,571$ ve $t_{5,0,05}=2,015 ;$ CAR $_{11}$ için $t_{10,0,005}=3,169 t_{10,}$ $0,025=2,228$ ve $t_{10,0,05}=1,812$. 
30.12.2020 olay gününde ise istatistiki olarak anlamlı anormal getiri (AR) tespit edilmemiştir. Olayın kümülatif anormal getirisi incelendiğinde, 20 pozitif $\mathrm{CAR}_{6}$ 'dan 6 sektör endeksinin (XBANK, XELKT, XGMYO, XSGRT, XTRZM, XUMAL) değerlerinin anlamlı olduğu görülmüştür. Bu endekslerden yaklaşı \%12 ile en çok kümülatif anormal getiri elde eden turizm sektör endeksi olurken, ardından $\% 8$ ile gayrimenkul yatırım ortaklığ gelmektedir. $\mathrm{CAR}_{11}$ değerlerinde ise 21 pozitif kümülatif anormal getirinin sadece 14 'ün (XBANK, XGIDA, XGMYO, XHOLD, XILTM, XMESY, XSGRT, XTAST, XTEKS, XTRZM, XUHIZ, XUMAL, XUSIN, XUTEK) anlamlı olduğu sonucuna varılmıştır. Pozitif en çok kümülatif anormal getiri sağlayan sektör endeksleri $\% 18, \% 9$ ve $\% 7$ ile sırasıyla turizm, metal eşya makina ve gida sektör endeksi olmuştur.

\section{Sonuç ve Çıkarımlar}

Bu çalışma, DSÖ tarafından pandeminin ilanı ve Türkiye'de ilk vakanın görüldüğü olay günü olan 11 Mart 2020, Türkiye'de Covid-19 kaynaklı ilk ölümün gerçekleştiği 17 Mart 2020 ve Türkiye'ye CoronaVac aşının ilk partisinin geldiği olay günü olan 30 Aralık 2020 tarihlerinin Borsa İstanbul sektör endeksleri üzerindeki etkisini incelemektedir. Beklenildiği üzere ilk olay günü ve ikinci olay gününün hisse senetleri üzerinde anormal kayıplara neden olduğu ortaya konulmuştur. Üçüncü olay gününün ise beklentiler doğrultusunda hisse senetleri üzerinde pozitif anormal getirilere neden olduğu tespit edilmiştir.

11 Mart 2020 gününün 10 günlük olay penceresinden kümülatif anormal kayba neden olduğu sektörlere bakıldığında, spor (-\%49) ve turizm sektörün (-\%42) en fazla kayıp yaşayan sektörler olduğu tespit edilmiştir. Bunun sebebinin pandeminin ilanı ile gelen seyahat kısıtlamaları olduğu düşünülmektedir. Spor ve turizmin yanı sıra Türkiye'nin sanayi sektöründe ara mal ithal eden pozisyonda olan bir ülke olması nedeniyle süreçte yaşanabilecek tedarik sorunu endişesi metal eşya makina, sınai ve metal ana endekslerinde de hem olay gününde anormal kayıplara hem de ilerleyen günlerde kümülatif anormal kayıplara sebep olduğu görülmüştür. Diğer taraftan aynı olayın ticaret (\%8) ve hizmetler (\%2) sektöründe olayın ilk gününde pozitif anormal getiriler yarattığı görülmüştür. Ortaya çıkan bu sonucun nedenin ise pandeminin etkisiyle birlikte arzda yaşanabilecek kısıtlamaların endişesiyle alışveriş taleplerini artıran tüketici davranışları kaynaklı olduğu düşünülmektedir.

Covid-19 kaynaklı ilk ölümün yaşandığı 17 Mart 2020 gününün yarattığı anormal kaybın 11 Mart 2020 gününe kiyasla daha düşük olduğu ve hatta kümülatif etkisine bakıldığında istatistiki olarak anlamlı bir anormal getirinin ya da kaybın yaşanmadığı görülmektedir. Turizm, taş toprak, kimya ve ulaştırma gibi sektör endekslerinde olay günü anormal kayıplar ortaya çıkmış olsa da olayın ertesi günü açıklanan "Ekonomik İstikrar Kalkanı" paketinin olumlu etkisi ile birlikte kümülatif anormal kayıpların oluşmasının engellendiği tahmin edilmektedir. 
Özdemir, K. \& B. Hiçyılmaz (2022), "COVID-19 ve Aşı Haberlerinin Borsa İstanbul

Sektör Endekslerine Etkisi: Bir Olay Etüdü Analizi”, Sosyoekonomi, 30(51), 471-486.

Pandemi sürecinin bitirilmesine yönelik önemli bir adım olan aşı süreci ile ilgili Türkiye için somut bir gelişmenin yaşandığı 30 Aralık 2020 tarihinin beklentiler doğrultusunda sektör endeksleri üzerinde kümülatif anormal getirilere neden olduğu görülmektedir. Çalışmada ele alınan ilk iki olumsuz olay gününde en çok anormal kayıp yaşayan sektörlerden birisi olan turizm endeksinin olumlu aşı haberi ile birlikte en çok anormal getiri elde eden sektör endeksi olduğu tespit edilmiştir. Seyahat kısitlamalarının belirli tedbirler ölçüsünde gevşetilmesi ve aşılamanın tüm dünya genelinde yaygınlaşması sektöre ilişkin olumlu beklentileri artırmıştır. Çin'den sipariş edilen aşının ilk partisinin gelişi ve yurt içinde de süren yerli aşı çalışmaları turizmden sonra en çok metal eşya makina, gıda ve sigorta endeksinde kümülatif anormal getirilere neden olmuştur.

Tüm dünyayı etkisi altına alan ve önceden tahmin edilemeyen pandemi gibi ani olayların hisse senedi piyasası üzerinde anormal getiri ve kayıplara neden olduğu literatürde yer alan çalışmalardan da görülmektedir. Dolayısıyla Borsa İstanbul'da işlem yapan yatırımcıların piyasaya düşecek olağan dışı haberlerin olası etkilerini doğru yorumlaması piyasada ortaya çıkacak anormal getiri ve kayıplara karşı hazırlıklı olmasını sağlayacaktır. Haberin niteliği ve sektörlere olası etkilerinin ön görülmesi ortaya çıkacak anormal getirileri el etmek için bir firsat, yaşanabilecek anormal kayıpların önlenmesi için ise bir olanaktır. Böyle bir durumda doğru bir analiz sonucunda anormal kayıpların yaşanılacağ düşünülüyorsa alternatif yatırım araçları tercih edilebilir veya anormal getirilerin ortaya çıkacağı düşünülüyor ise bu araçlardan hangisinin daha yüksek getiri potansiyeli sağlayacağ 1 kıyaslanarak bu doğrultuda işlem yapılabilir.

\section{Kaynaklar}

Aksoy, M. (2014), "The Effects of Terrorism on Turkish Stock Market", Ege Academic Review, $14(1), 31-41$.

AlAli, M.S. (2020), "The Effect of WHO COVID-19 Announcement On Asian Stock Markets Returns: An Event Study Analysis”, Journal of Economics and Business, 3(3), 10511054.

Alam, M.N. et al. (2020), "Stock Market Response During COVID-19 Lockdown Period in India: An Event Study", The Journal of Asian Finance, Economics, and Business, 7(7), 131137.

Al-Awadhi et al. (2020), "Death And Contagious Infectious Diseases: Impact of the COVID-19 Virus On Stock Market Returns", Journal of Behavioral and Experimental Finance, 27, 100326.

Ashraf, B.N. (2020), “Stock markets' reaction to COVID-19: Cases or Fatalities?”, Research in International Business and Finance, 54, 101249.

Bash, A. (2020), "International Evidence of COVID-19 and Stock Market Returns: An Event Study Analysis", International Journal of Economics and Financial Issues, 10(4), 34-38.

Brown, S.J. \& J.B. Warner (1985), “Using Daily Stock Returns: The Case of Event Studies”, Journal of Financial Economics, 14(1), 3-31.

Chen, A.H. \& T.F. Siems (2004), "The Effects of Terrorism on Global Capital Markets", European Journal of Political Economy, 20, 349-366. 
Chowdhury, E.K. \& M.Z. Abedin (2020), "COVID-19 Effects on the US Stock Index Returns: An Event Study Approach", Accounting, Auditing \& Accountability Journal, 1-31.

Çetin, A.C. (2020), “Koronavirüs (Covid-19) Salgınının Türkiye'de Genel Ekonomik Faaliyetlere ve Hisse Senedi Borsa Endeksine Etkisi”, Mehmet Akif Ersoy Üniversitesi Uygulamal Bilimler Dergisi, 4(2), 341-362.

Çoban, O. vd. (2020), “Covid-19 Krizinin Finansal Piyasalara Etkisi: Türkiye Örneği”, Gaziantep University Journal of Social Sciences, (Special Issue), 506-519.

Dyckman, T. et al. (1984), “A Comparison of Event Study Methodologies Using Daily Stock Returns: A Simulation Approach”, Journal of Accounting Research, 1-30.

Fama, E.F. (1970), "Efficient Capital Markets: A Rewiew of Theory and Emprical Work", Journal of Finance, 25(2), 383-417.

Goodell, J.W. \& T.L.D. Huynh (2020), "Did Congress trade ahead? Considering the reaction of US industries to COVID-19”, Finance Research Letters, 36, 101578.

Göker, İ.E. et al. (2020), "The Impact of the COVID-19 (Coronavirus) on The Borsa Istanbul Sector Index Returns: An Event Study", Gaziantep University Journal of Social Sciences, (Special Issue), 14-41.

Gülhan, Ü. (2020), “Covid-19 Pandemisine BIST 100 Reaksiyonu: Ekonometrik Bir Analiz”, Turkish Studies, 15(4), 497-509.

He, P. et al. (2020), "COVID-19's Impact on Stock Prices Across Different Sectors: An Event Study Based on the Chinese Stock Market", Emerging Markets Finance and Trade, 56(10), 2198-2212.

Heyden, K.J. \& T. Heyden (2021), "Market Reactions to the Arrival and Containment of COVID-19: An Event Study", Finance Research Letters, 38, 101745.

Huo, X. \& Z. Qiu (2020), "How does China's Stock Market React to the Announcement of the COVID-19 Pandemic Lockdown?", Economic and Political Studies, 8(4), 436-461.

Kilıç, Y. (2020), “Borsa İstanbul'da COVID-19 (Koronavirüs) Etkisi”, Journal of Emerging Economies and Policy, 5(1), 66-77.

Liu, H. et al. (2020), "The COVID-19 Outbreak and Affected Countries Stock Markets Response", International Journal of Environmental Research and Public Health, 17(8), 2800.

Maneenop, S. \& S. Kotcharin (2020), "The impacts of COVID-19 on the Global Airline Industry: An Event Study Approach", Journal of Air Transport Management, 89, 101920.

Öztürk, Ö. et al. (2020), "Effect of COVID-19 Outbreak on Turkish Stock Market: A Sectoral-Level Analysis", Hitit University Journal of Social Sciences Institute, 13(1), 56-68.

Pandey, D.K. \& V. Kumari (2021), "Event study on the Reaction of the Developed and Emerging Stock Markets to the 2019-nCoV Outbreak", International Review of Economics \& Finance, 71, 467-483.

Peker, Y. \& E. Demirhan (2020), “COVID-19 Küresel Salgınının Borsa İstanbul'daki Sektörel Etkileri”, TEPAV Değerlendirme Notu, N202012, $<$ https://www.tepav.org.tr/upload/files/15867521880.COVID_19_Kuresel_Salgininin_Borsa_Istanbuldaki_Sektorel_Etkileri.pdf >, 28.01.2021.

Rahman, M.L. et al. (2021), "The COVID-19 Outbreak and Stock Market Reactions: Evidence from Australia”, Finance Research Letters, 38, 101832. 
Saka-Ilgın, K. \& S.S. Sarı (2020), "COVID-19 Pandemisinin Hisse Senedi Piyasalarına Etkisi: Vaka ve Ölümlerin Yoğun Olduğu Ülkeler ile Türkiye İncelemesi”, Karadeniz Sosyal Bilimler Dergisi, 12(23), 434-453.

Schwert, G.W. (1981), "Using Financial Data to Measure Effects of Regulation”, Journal of Law and Economics, 24, 121-158.

Singh, B. et al. (2020), "The Outbreak of COVID-19 and Stock Market Responses: An Event Study and Panel Data Analysis for G-20 Countries", Global Business Review, 1-26.

Sun, Y. et al. (2021), "The impact of COVID-19 on the Chinese Stock Market: Sentimental or Substantial?", Finance Research Letters, 38.

Tayar, T. vd. (2020), “Covid-19 Krizinin Türkiye'deki Sektörler Üzerinde Etkileri: Borsa İstanbul Sektör Endeksleri Araştırması", Van Yüzüncü Yıl Üniversitesi Sosyal Bilimler Enstitüsü Dergisi, (Salgın Hastalıklar Özel Sayıs1), 293-320.

Xiong, H. et al. (2020), "Which Firm-Specific Characteristics Affect The Market Reaction of Chinese Listed Companies to the COVID-19 Pandemic?", Emerging Markets Finance and Trade, 56(10), 2231-2242.

Y1ldız-Contuk, F. (2020), “Covid-19’un Borsa İstanbul Üzerindeki Etkisi: Bir ARDL Sınır Testi Modeli”, Muhasebe ve Finansman Dergisi, 89, 101-112.

Yong, H.H.A. \& E. Laing (2020), “Stock Market Reaction to COVID-19: Evidence from U.S. Firms' International Exposure", International Review of Financial Analysis, 76, 101656.

Zeren, F. \& A.E. Hizarc1 (2020), "The Impact of Covid-19 Coronavirus on Stock Markets: Evidence From Selected Countries”, Muhasebe ve Finans Incelemeleri Dergisi, 3(1), 78-84. 